\title{
Airborne Emissions from Mn Ferroalloy Production
}

\author{
IDA TERESIA KERO, ${ }^{1,5}$ PER ANDERS EIDEM, ${ }^{2}$ YAN MA, ${ }^{3}$ \\ HEGE INDRESAND,${ }^{4}$ THOR ANDERS AARHAUG,${ }^{1}$ and \\ SVEND GRÅDAHL ${ }^{1}$
}

\begin{abstract}
1.-SINTEF Industry, Alfred Getz vei 2, 7465 Trondheim, Norway. 2.-SINTEF Helgeland, Postboks 1364, 8602 Mo i Rana, Norway. 3.-Norwegian University of Science and Technology, Alfred Getz vei 2, 7491 Trondheim, Norway. 4.-Teknova NorceResearch, Tordenskjolds gate 9, 4612 Kristiansand, Norway. 5.—e-mail: ida.kero@sintef.no
\end{abstract}

\begin{abstract}
Airborne emissions from metal production represent a health, safety, and environmental challenge to which more and more attention is being directed. Industries worldwide, as well as authorities and others, are resolute in their aim of limiting, reducing, and ultimately eliminating these emissions. Many lessons can be learned by sharing information between industrial branches, as many industries face similar challenges. Certain challenges are, however, highly branch specific. For the Mn ferroalloy industry, such examples include the types of dust generated in the primary processes and the management of polycyclic aromatic hydrocarbons (PAHs) and mercury with respect to furnace design and operation. This article covers airborne emissions from manganese ferroalloy production, including greenhouse gases, nitrogen oxides $\left(\mathrm{NO}_{x}\right)$, sulfurous gases, PAH, airborne particulate matter, and trace elements, including mercury and other heavy metals. The aim is to summarize current knowledge in a state-of-the-art overview intended to introduce fresh industry engineers and academic researchers to the technological aspects relevant to reduction of airborne emissions.
\end{abstract}

\section{INTRODUCTION}

In the task of reducing and abating airborne emissions from an industrial site or process, the scarcity of information represents a difficulty in itself. Several industrial initiatives both within corporations and based on external knowledgesharing between businesses and countries have achieved great results in this area. Although great progress has been made, and emission levels are constantly and continuously decreasing, relatively little has been openly published. The interdisciplinary nature of this topic increases the difficulties in finding and collecting appropriate information. However, many lessons can be learned by sharing information between industrial branches, and if possible, good examples should be documented and published to allow cross-fertilization of ideas.

This review article focuses on the manganese ferroalloy industry and its specific emission types and sources. The aim is a state-of-the-art overview of the field, and our hope is that this article may constitute a starting point for any professionals or laymen in search of a brief introduction with suggestions for further reading. The content is based on open literature but also cites some selected unpublished material that was deemed important for a more complete description of documented knowledge. The article specifically covers the following emission types: greenhouse gases (GHGs), nitrogen oxides $\left(\mathrm{NO}_{x}\right)$ and sulfurous gases $\left(\mathrm{SO}_{x}\right.$, $\mathrm{H}_{2} \mathrm{~S}$ ), airborne particulate matter (PM, dust), polyaromatic hydrocarbons (PAHs), heavy metals, and trace elements. Certain methods and challenges related to the measurement and monitoring of these pollutants are also described. The scope of this article includes formation mechanisms, emission factors, and emission measurements of certain types of airborne emissions generated throughout the primary manganese ferroalloy production process. This excludes ore excavation procedures, transport, and electricity generation. 


\section{BACKGROUND}

Manganese ferroalloys have numerous applications which impact our daily lives as consumers, most notably as alloying components in steel and aluminum. ${ }^{1}$ There are two types of manganese ferroalloys, viz. ferromanganese (FeMn) and silicomanganese (SiMn). Unrefined, high-carbon ferromanganese ( $\mathrm{HC} \mathrm{FeMn}$ ) can be refined into either medium-carbon (MC) or low-carbon (LC) FeMn. Similarly, SiMn is categorized into standard, low carbon (LC), or ultralow carbon (ULC) grades. Typical compositions are presented in Table I. Although not included in this table, iron $(\mathrm{Fe})$ is always a major component of all ferroalloys.

Global manganese ferroalloy production totaled 19.4 million metric tons in 2014 , of which production of SiMn and FeMn accounted for 12.7 and 6.7 million metric tons, respectively. Of FeMn production, the HC grade dominated the market. China is the leading producer and consumer of manganese ferroalloys, representing around 60\% of the manganese ferroalloy world market. ${ }^{3}$ More details of production by country are presented in Table II.

\section{METHODOLOGY}

This review article is mainly based on information available in open literature. Database searches using library online search engines were carried out for all the different topics covered in this article. Some of the topics, however, lack significant open literature. The reasons for this may vary, but this typically has to do with company confidentiality and/or work being carried out in projects which lack funding for open publication. In addition, the industrial relevance of these efforts is typically valued by their practical applicability rather than the educational and communicational benefits which may be expected from publishing.

Very often, when this type of work is published, it is in the framework of a conference, such as the International Ferroalloy Congress (INFACON). Articles presented at INFACON are typically subject to some form of peer review, but the proceedings are not always published in such a way as to make them searchable. As such, this and other conferences of high industrial relevance are categorized as "obscure" to information-seeking individuals outside the core community of metallurgists and engineers.
For this article, we obtained permission from authors and industrial partners to include some previously unpublished work. This includes industrial and academic reports, some of which are open but difficult to find, as library and online search engines will not typically find them. Some reports are even classified as confidential, but we received authorization to include some of their main findings and conclusions. For the sake of completeness, interviews and correspondence with key industrial personnel were also carried out to ensure that the information presented herein is up to date, complete, and correct to the best of the authors' knowledge. Such inquiries are cited as "personal communications."

The subject of airborne emissions is inherently interdisciplinary and spans a vast range of different scientific fields, such as atmosphere and aerosol physics, chemistry, process metallurgy, occupational hygiene, and environmental monitoring. This article focuses on emission types, concentrations, characteristics, and abatement methods. Studies in neighboring fields, such as personal exposure and epidemiology, are sometimes mentioned but never detailed. Nor are studies on aquatic or soil systems covered here.

\section{MANGANESE FERROALLOY PRODUCTION}

In the following section, the production of SiMn and FeMn in the submerged arc furnace (SAF) is briefly described. For more detailed descriptions, we refer to textbooks by Olsen et al. ${ }^{2}$ and Gasik et al. ${ }^{5}$ The submerged arc furnace (SAF) is the dominant furnace process for both FeMn and SiMn production. Figure 1 schematically illustrates a typical Mn-ferroalloy smelter. The molten metal obtained from the furnace can either be cast (as HC FeMn or standard SiMn), or the metal can go through further refining, e.g., in a manganese oxygen refining (MOR) reactor.

\section{RAW MATERIALS AND PRETREATMENTS}

The raw materials used for FeMn are manganese ore, sinter, reductants, iron sources, and fluxes. For SiMn, the raw materials also include quartzite, and $\mathrm{MnO}$-rich slag from the FeMn furnace can also be used as a raw material (in the so-called duplex process). ${ }^{2}$ Some producers add silicon to the furnace to achieve the correct $\mathrm{Si}$ content. ${ }^{6}$ In addition, slag,

Table I. Typical composition of Mn ferroalloys ${ }^{2}$

\begin{tabular}{|c|c|c|c|c|c|c|}
\hline & Mn (\%) & Si (\%) & C (\%) & $\mathbf{P}(\%)$ & S (\%) & B (ppm) \\
\hline HC FeMn & $74-78$ & 0.3 & 7.5 & 0.2 & - & - \\
\hline MC FeMn & $80-83$ & 0.6 & $0.5-1.5$ & 0.2 & - & - \\
\hline LC FeMn & $80-83$ & 0.6 & $\leq 0.5$ & 0.2 & & \\
\hline SiMn & 67 & $14-20$ & $1.5-2$ & $0.15-0.2$ & 0.02 & 200 \\
\hline LC SiMn & $59-63$ & $26-31$ & $0.05-0.5$ & 0.1 & 0.01 & 100 \\
\hline ULC SiMn & $58-62$ & $27-31$ & $\leq 0.05$ & 0.05 & 0.01 & 100 \\
\hline
\end{tabular}


Table II. World production of FeMn and SiMn alloys

\begin{tabular}{|c|c|c|c|c|c|c|}
\hline \multirow[b]{2}{*}{ Nation } & \multicolumn{2}{|c|}{2012} & \multicolumn{2}{|c|}{2013} & \multicolumn{2}{|c|}{2014} \\
\hline & FeMn & SiMn & FeMn & SiMn & FeMn & SiMn \\
\hline China & 3320.0 & 7400.0 & 3600.0 & 7700.0 & 3300.0 & 7900.0 \\
\hline Georgia & & 261.1 & & 254.1 & & 256.7 \\
\hline India & 493.3 & 1552.6 & 564.4 & 1643.2 & 666.1 & 1740.6 \\
\hline Japan & 436.1 & 52.3 & 460.9 & 24.7 & 463.3 & 25.0 \\
\hline Norway & 325.9 & 271.4 & 306.7 & 301.4 & 312.4 & 314.3 \\
\hline South Africa & 509.8 & 148.8 & 558.3 & 133.6 & 552.8 & 228.1 \\
\hline Ukraine & 163.9 & 823.1 & 88.6 & 724.9 & 103.0 & 840.9 \\
\hline Other & 118.1 & 168.4 & 97.2 & 128.1 & 1299.4 & 1394.4 \\
\hline World total, BF & 462 & & 482 & & 487 & \\
\hline World total, SAF & 5900 & 12,000 & 6260 & 12,300 & 6210 & 12,700 \\
\hline
\end{tabular}

The top five countries in terms of FeMn and SiMn production in 2014 are shown. Data in thousands of metric tons. ${ }^{4} B F$ blast furnace; $S A F$ submerged arc furnace.

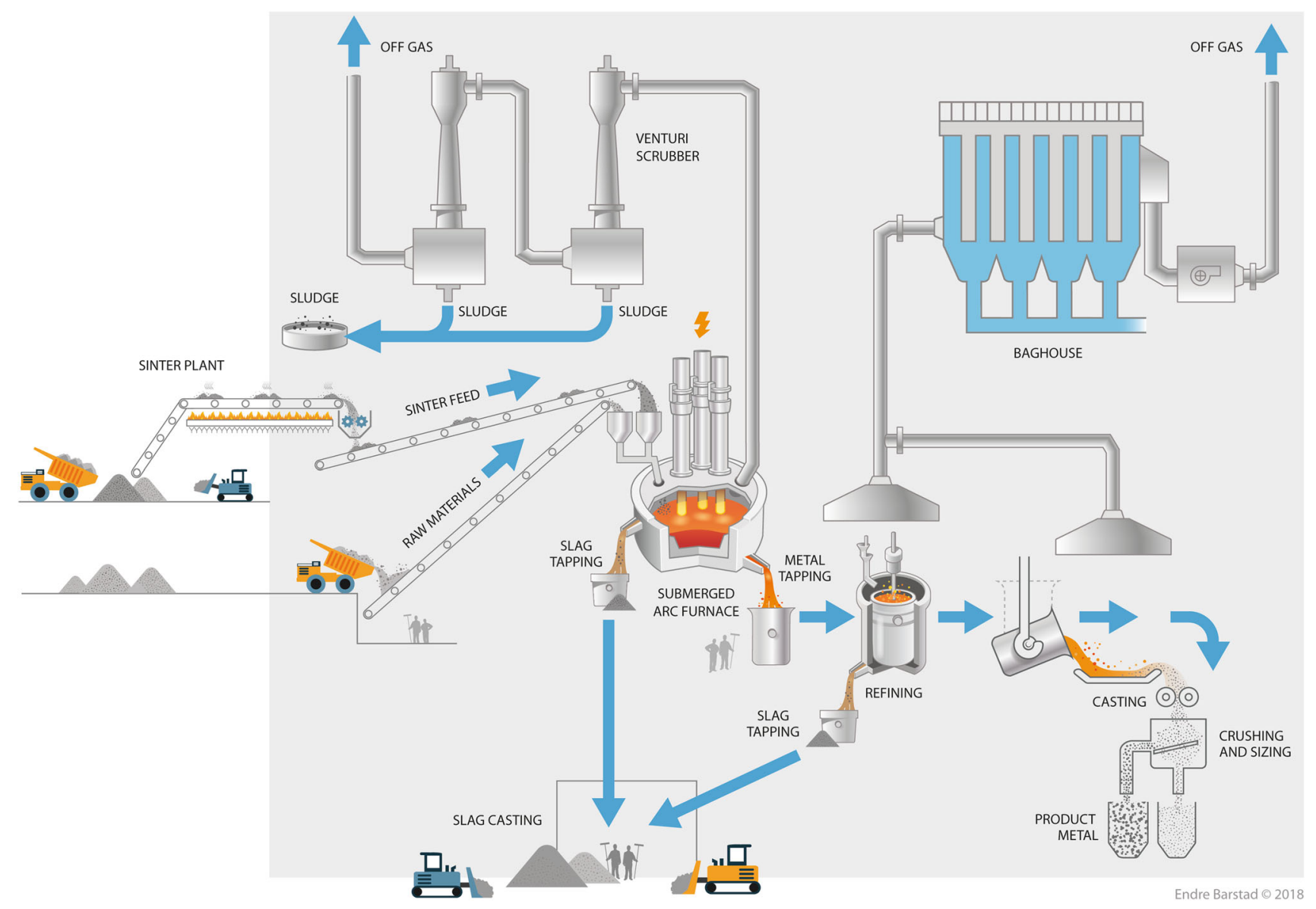

Fig. 1. Schematic overview of a typical Mn-ferroalloy production plant.

metal, and fines that originate from handling and treatment of raw materials, finished goods, spillage, skimming, etc. may be fed back to a furnace.

Prior to feeding the raw materials into the furnace, they are typically crushed to around $80 \mathrm{~mm}$ then screened to remove undersized
$(<6 \mathrm{~mm})$ fragments, often called fines. ${ }^{2,7,8}$ Sintering is the most common agglomeration technique used for manganese ore. ${ }^{2,9,10}$ In the sintering process, manganese ore fines are mixed with coke breeze and other particulate materials, such as dust from filters. The sinter bed is ignited by a heating 


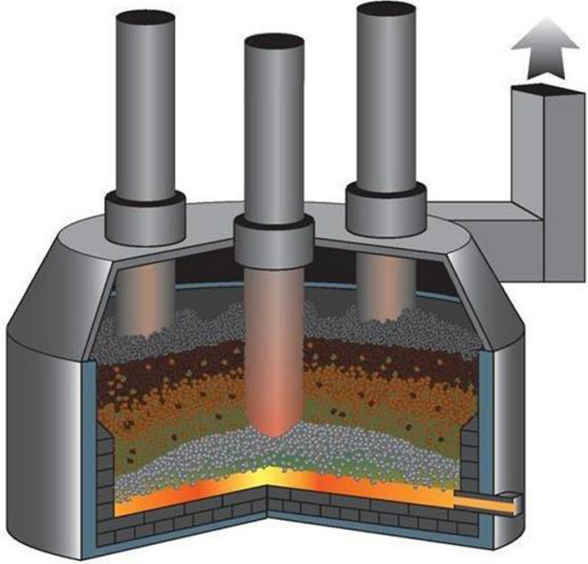

Fig. 2. Schematic illustration of a sealed submerged arc furnace for Mn-ferroalloy production. Reproduced with permission from $M$. Tangstad and M. Syvertsen.

source such as oil or CO gas. ${ }^{10,11}$ During the sintering process, manganese dioxide $\left(\mathrm{MnO}_{2}\right)$ and carbonate compounds decompose, crystal-bound water is released, and ore fragments fuse together. Besides the size benefit of agglomeration, the decomposition of carbonates will decrease the energy consumption of the furnace. The decomposition of manganese dioxide, on the other hand, will increase the specific carbon and energy consumption of the SAF. Agglomeration by pelletization of $\mathrm{Mn}$ ores has also been tried on large scale,${ }^{11,12}$ but is not in production today. ${ }^{13,14}$

\section{THE FURNACE PROCESS AND REFINING}

A sealed submerged arc furnace is illustrated in Fig. 2. Furnace size and construction vary greatly, with transformer capacity up to $102 \mathrm{MW},{ }^{15}$ and can roughly be divided into open, covered (semiopen), and sealed (closed) furnaces. A sealed furnace generally has a standing charge, while open and semiopen furnaces have batch or semicontinuous charging with the possibility of stoking, which may constitute a safety advantage. The main difference, however, lies in the furnace cover design, where open and covered hoods allow air access so that furnace off-gases are completely combusted. In sealed furnaces, only limited combustion occurs, thus the off-gas may be collected and used for various purposes. Off-gases mainly consist of $\mathrm{CO}$ and $\mathrm{CO}_{2}$ with some $\mathrm{H}_{2}$, moisture, and dust. Their composition is highly variable and depends on the raw material mix and operating conditions. The different furnace cover designs also influence the charging methods, which, again, may influence the environmental impact. ${ }^{16}$

Below the charging level, the general process is the same, independent of furnace size and hood. Theoretically, the furnace process is often divided into four zones: the preheating zone, the prereduction zone, the smelting zone, and the coke bed zone. The raw materials are added (charged) to the top of the SAF and thus enter the preheating zone, where they are dried and low-temperature reactions take place. The typical gas temperature at the charge top in a sealed furnace will be in the range of $80^{\circ} \mathrm{C}$ to $700^{\circ} \mathrm{C},{ }^{2,6,17}$ depending on the type of process and operating conditions. In an open furnace, the combustion at the charge surface will result in a higher temperature. ${ }^{18}$

The prereduction reactions take place above approximately $300^{\circ} \mathrm{C}$. Prereduction of higher oxides occurs via exothermic reactions, leading to lower specific coke and energy consumption. Fluxes added as carbonates, typically limestone and/or dolomite, will decompose at temperatures between $300^{\circ} \mathrm{C}$ and $900^{\circ} \mathrm{C}$, depending on the material. ${ }^{19}$ Their decomposition is endothermic. Reduction of $\mathrm{Mn}_{3} \mathrm{O}_{4}$ by $\mathrm{CO}$ gas to $\mathrm{MnO}$ may also occur at temperatures above $800^{\circ} \mathrm{C}$, leading to the Boudouard reaction and thus increased specific energy and carbon consumption. ${ }^{7,20}$

When the charged materials reach a temperature of around $1250^{\circ} \mathrm{C}$, the ore will start melting and forming a slag phase. This occurs close to the socalled coke bed, illustrated as grey granules in Fig. 2. The coke bed zone mainly consists of a mixture of solid carbon particles, liquid slag, alloy, and some gas (mainly $\mathrm{CO}$ ) from the final reduction steps. The main reduction of $\mathrm{MnO}$ takes place at the surface of the coke bed. ${ }^{2}$ The final reduction steps are strongly endothermic, and energy is supplied by Ohmic heating from current flow through the liquid slag and solid carbon particles. ${ }^{2,6}$ There may, however, be some limited arcing or sparking, which contribute to the total energy input. ${ }^{21}$ The slag and alloy are tapped from the furnace.

Mn-ferroalloys are refined by decarburization in a manganese oxygen refining (MOR) process. The MOR process involves blowing oxygen through a top lance as well as bottom tuyeres into a refining converter holding the liquid alloy. Stirring gases (such as $\mathrm{N}_{2}, \mathrm{CO}_{2}$, and $\mathrm{Ar}$ ) may also be injected into the melt through the bottom tuyeres. ${ }^{22}$

\section{FURNACE OFF-GAS AND GAS CLEANING}

The furnace off-gas is a mixture of different gas species such as $\mathrm{CO}, \mathrm{CO}_{2}, \mathrm{H}_{2}, \mathrm{~N}_{2}, \mathrm{O}_{2}$, and moisture. In addition, the gas typically carries particulate matter, $\mathrm{SO}_{2}, \mathrm{NO}_{x}$, and organic components. Offgases from sealed SAFs for manganese ferroalloy production are very rich in $\mathrm{CO}(\mathrm{g})$. The composition of the off-gas varies considerably, depending on various parameters such as the fraction of higher oxides fed into the furnace and the operational conditions of the furnace. The CO content may vary from 45 vol. $\%$ to over 90 vol. $\% .^{10,23-25}$ The furnace off-gas is combustible with high potential energy and may be used in, for example, electricity generation or ore pretreatment. ${ }^{10,26,27}$ Typical 
compositions as well as chemical potentials of the off-gas from sealed FeMn- and SiMn-producing furnaces are presented in Table III.

The furnace off-gas handling system is an important part of a submerged arc furnace and vital for stable and profitable furnace operation. Any problem in the off-gas system can lead to stoppage of the entire furnace operation, with severe operational, environmental, and economic consequences.

Open furnaces typically employ baghouse filters to capture and collect particulate matter dispersed in the gas stream for disposal or reuse in the process. ${ }^{28,30}$ The off-gas from an SAF is collected by the furnace hood, typically located $>1 \mathrm{~m}$ above the charge to allow for stoking. By controlling the amount of excess air, the temperature of the offgas can be regulated to a certain degree. The off-gas is then typically passed through a cyclone device to separate and collect coarser particles. This stage also prevents sparks from reaching the filters. A baghouse system can hold several hundred bag filters. The pressure drop over the filters increases as filter cake forms (i.e., as dust builds up on the filter surface), and the filters can be cleaned by reverse air cleaning or a pulse jet air system. ${ }^{28,31}$

Furnace off-gas systems for sealed furnaces are composed of several parts, including off-gas uptakes on the furnace hood, a dry zone, and wet scrubbers. In addition, there may be filters and a mercury cleaning unit. The particulate matter and tarry components in the furnace off-gas are normally removed from the gas phase using wet contactor cleaning units, so-called Venturi scrubbers. The scrubbing action in wet-type contactors is produced by passing the gas stream by a liquid stream, so that the liquid (often atomized into small droplets) can absorb and remove unwanted components. ${ }^{32-35}$ Several scrubbers are usually installed in series with a gravity or inertia impact separator to remove the scrubbing liquid from the gas stream. ${ }^{32}$ The particulate matter removed from the off-gas is suspended in water, in a slurry mixture often referred to as "sludge." Fine particles $(<5 \mu \mathrm{m})$ in added raw materials may be carried by the gas directly to the Venturi scrubbers. ${ }^{28}$ Examples of sludge analyses are presented in Table IV. Attempts are made to agglomerate sludge and feed it back into the furnace, ${ }^{36-40}$ but the sludge typically contains $\mathrm{K}, \mathrm{Na}, \mathrm{Zn}, \mathrm{Pb}, \mathrm{Hg}$, As, $\mathrm{Cd}$, water, and organic components, which may be detrimental to furnace operation. ${ }^{41-43}$

\section{EMISSION TYPES}

A lifecycle analysis (LCA) by the International Manganese Institute (IMnI) for global Mn alloy production (including mining, smelting, and associated upstream processes) revealed that the environmental impact of this industry is very sensitive to the mode of electricity generation. The degree of fossil dependency of electricity grids is a crucial factor in their specific environmental footprint. ${ }^{3,44,45}$ Some LCA results are presented in Table V.

\section{GREENHOUSE GASES}

Production of manganese ferroalloys results in greenhouse gas (GHG) emissions, with $\mathrm{CO}_{2}$ being the primary GHG species, whereas other gases such as $\mathrm{CH}_{4}$ and $\mathrm{N}_{2} \mathrm{O}$ account for $<1 \%$ of the total emission of $\mathrm{CO}_{2}$ equivalents. ${ }^{2,46}$ Primary GHG emissions are produced in the submerged arc furnace from combustion of coke, coal, and other reductants. The primary gas species generated in the SAF is CO, which in open or covered furnaces is burnt to $\mathrm{CO}_{2}$ above the charge level. For sealed furnaces, the $\mathrm{CO}$ is either flared or utilized, e.g., for generation of electricity in boilers. ${ }^{47}$ Haque et al. ${ }^{48}$ pointed out that coke and coal usage contributed approximately $60 \%$ of the total GHG emissions from ferroalloy production processes in Australia. This emphasizes the potential to reduce greenhouse gas emissions by replacing fossil reductants with biomass-based renewable carbon materials. Other GHG sources include consumable graphite and Søderberg electrodes, as well as the calcination reactions of carbonates in the ores and flux materials added to the SAF. ${ }^{49}$

The 2006 IPCC Guidelines outline several approaches for calculating $\mathrm{CO}_{2}$ emissions from ferroalloy production. Emission factors for manganese ferroalloy production are presented in Table VI. These emission factors were calculated for tapped metal. Indirect emissions from the ferroalloys industry, related to extraction and production of raw materials and electric energy, are not included in these numbers. ${ }^{46}$ Several studies have

Table III. Typical chemical energy and composition of off-gas from manganese ferroalloy furnaces

\begin{tabular}{|c|c|c|c|c|c|c|c|}
\hline \multirow[b]{2}{*}{$\underline{\text { Furnace Production }}$} & \multicolumn{5}{|c|}{ Content (vol.\%) in Off-Gas } & \multirow[b]{2}{*}{ Chemical Energy (kWh/ton) } & \multirow{2}{*}{$\begin{array}{c}\text { Temperature } \\
\text { Range }\left({ }^{\circ} \mathbf{C}\right) \\
\end{array}$} \\
\hline & CO & $\mathrm{CO}_{2}$ & $\underline{\mathbf{H}_{2}}$ & $\mathbf{N}_{2}$ & $\mathbf{O}_{2}$ & & \\
\hline $\begin{array}{l}\mathrm{FeMn}^{28} \\
\mathrm{SiMn}^{28,29}\end{array}$ & $\begin{array}{c}62.5 \\
60-70\end{array}$ & $\begin{array}{c}24.5 \\
11-13\end{array}$ & $\begin{array}{l}8.5 \\
4-8\end{array}$ & $\begin{array}{c}4 \\
15-20\end{array}$ & $\begin{array}{c}0.5 \\
0.02-0.5\end{array}$ & $\begin{array}{l}1913 \\
2247\end{array}$ & $\begin{array}{l}100-250 \\
350-500\end{array}$ \\
\hline
\end{tabular}


Table IV. Composition of fine particulate matter removed from off-gases as sludge (wt.\%)

\begin{tabular}{|c|c|c|c|c|c|c|c|c|c|c|}
\hline References & Process & MnO & $\underline{\mathrm{SiO}_{2}}$ & $\mathbf{A l}_{2} \mathbf{O}_{3}$ & FeO & $\mathrm{Fe}_{2} \mathbf{O}_{3}$ & $\mathbf{C a O}$ & MgO & $\mathrm{MnCO}_{3}$ & $\underline{\mathbf{K}_{2} \mathbf{O}}$ \\
\hline Kadkhodabeigi et al. ${ }^{32}$ & FeMn & 45 & 32 & 11 & 8 & & 3 & 1 & & \\
\hline Olsen et al. ${ }^{2}$ & FeMn & & 5 & 2 & & 2 & 4 & & 75 & 4 \\
\hline Olsen et al. ${ }^{2}$ & SiMn & & 25 & 3 & & 1 & 6 & & 40 & 6 \\
\hline
\end{tabular}

Table V. Airborne emission indicators per $\mathrm{kg}$ of $\mathrm{Mn}$ alloy product ${ }^{45}$

\begin{tabular}{|c|c|c|c|c|c|}
\hline Emission type & $\underline{\text { SiMn }}$ & $\begin{array}{c}\text { HC } \\
\text { FeMn }\end{array}$ & $\begin{array}{l}\text { Refined } \\
\text { FeMn }\end{array}$ & Ave. & $\begin{array}{c}\text { Contribution of primary } \\
\text { process }(\%)\end{array}$ \\
\hline Global warming potential $(\mathrm{GWP})\left(\mathrm{kg} \mathrm{CO}_{2} \mathrm{e}\right)^{\mathrm{a}}$ & 6.9 & 5.1 & 6.2 & 6.0 & 32 \\
\hline $\begin{array}{l}\text { Photochemical ozone creation potential } \\
(\mathrm{POCP})\left(\mathrm{g} \mathrm{C}_{2} \mathrm{H}_{4} \mathrm{e}\right)^{\mathrm{a}}\end{array}$ & 3.3 & 2.5 & 3.6 & 3.0 & 26 \\
\hline Acidification potential $(\mathrm{AP})\left(\mathrm{g} \mathrm{SO}_{2} \mathrm{e}\right)^{\mathrm{a}}$ & 52.5 & 35.4 & 49.6 & 45.0 & 14 \\
\hline Nitrogen oxides $\left(\mathrm{NO}_{x}\right)(\mathrm{g})^{\mathrm{b}}$ & 20.1 & 15.5 & 22.4 & 18.7 & 25 \\
\hline Sulfur oxides $\left(\mathrm{SO}_{x}\right)(\mathrm{g})$ & 37.5 & 23.9 & 31.5 & 30.9 & 9 \\
\hline Particulate matter (PM) (g) & 11.5 & 8.47 & 8.0 & 9.6 & 34 \\
\hline
\end{tabular}

aThe global warming potential, the photochemical ozone creation potential, and the acidification potential are given as their respective equivalents, calculated by CML 2001 mid-point method. ${ }^{b}$ For Norwegian smelters, these numbers are in the order of magnitude of $1-9$ g. ${ }^{29}$

Table VI. Generic $\mathrm{CO}_{2}$ emission factors for $\mathrm{Mn}$ ferroalloy production in tons of $\mathrm{CO}_{2}$ per ton of alloy produced

\begin{tabular}{|c|c|c|c|c|}
\hline & IPCC $2006^{51}$ & Holappa $2010^{25}$ & Sjardin $2003^{52}$ & Lindstad, Monsen, Osen $2010^{53}$ \\
\hline SiMn & 1.7 & 1.66 & 1.73 & 1.4 \\
\hline FeMn & 1.5 & 1.79 & - & 1.4 \\
\hline HC FeMn & - & - & 1.84 & 1.3 \\
\hline MC FeMn & - & - & - & 1.5 \\
\hline
\end{tabular}

shown that the total $\mathrm{CO}_{2}$ footprint, i.e., including up- and downstream activities, is very sensitive to the electricity mix. ${ }^{3,44,47,50}$

\section{NITROGEN OXIDES AND SULFUROUS GASES}

Nitrogen oxides, or $\mathrm{NO}_{x}$, is a common term for the gases $\mathrm{NO}$ and $\mathrm{NO}_{2} \cdot \mathrm{NO}_{x}$ emissions are important due to their role in atmospheric reactions creating fine particles and ozone smog. $\mathrm{NO}_{x}$ emissions are always reported as $\mathrm{NO}_{2}$, because $\mathrm{NO}$ is unstable and will react with atmospheric oxygen to $\mathrm{NO}_{2} . \mathrm{NO}_{x}$ formation is quite thoroughly described in literature, and theoretically, three principal formation mechanisms are identified: thermal, prompt, and fuel $\mathrm{NO}_{x}$. Prompt $\mathrm{NO}_{x}$ is considered ubiquitous but insignificant for high-temperature industrial processes. ${ }^{54-56}$ Fuel $\mathrm{NO}_{x}$ is the result of oxidation of nitrogen in combusted materials and may occur in an SAF if there is $\mathrm{N}$ in the raw materials. Thermal $\mathrm{NO}_{x}$ formation occurs only at very high temperatures, which allow direct reaction between $\mathrm{N}_{2}$ and $\mathrm{O}_{2}$ from the air. The high temperatures in the furnace and refining processes suggest that thermal $\mathrm{NO}_{x}$ is the dominant formation mechanism. ${ }^{57-61}$
An $\mathrm{LCA}^{44,45}$ showed that electricity generation is a major $(82 \%)$ contributor to the total $\mathrm{NO}_{x}$ emissions associated with the production of manganese ferroalloys. It is further seen that $8 \%$ (ca. $1.1 \mathrm{~g} \mathrm{NO}_{x}$ ) of the weighted average unit manganese alloy is contributed by the furnace process. Refining further contributes approximately $0.9 \mathrm{~g} / \mathrm{kg}$.

Sulfur is introduced into the manganese ferroalloy smelting process via the carbonaceous reducing agents such as metallurgical coke, charcoal, and coal. Sulfur may also enter the SAF in the HC FeMn slag sometimes used as a raw material for SiMn production. In metallurgical coke, sulfur may exist in the form of organic compounds, sulfides, and sulfates, but most of the sulfur in the charge is transferred into the slag phase during the smelting. ${ }^{62,63}$ Even though $\mathrm{SO}_{x}$ emissions are well known in this industry and many operators can testify to the occurrence of "foul smell" in certain areas and/or during certain operations, literature on this subject is surprisingly hard to come by. Airborne $\mathrm{SO}_{2}$ emissions are a mandatory part of environmental reports to authorities in many countries, and estimates of yearly plant emissions are readily available. These environmental reports are commonly based on element balance calculations from 
chemical analysis of solid materials. The elemental distributions by $\mathrm{Ma}$ et al. $^{63,64}$ give no account of gaseous species but suggest that $\mathrm{S}$ is upconcentrated in the PM. Sulfur is also a well-known contaminant in sludge. ${ }^{39,42}$

Very little literature on the formation of sulfurous gas emissions from $\mathrm{Mn}$ ferroalloy production has been found, but a couple of sources suggest that sulfurous gases are primarily released when hot metal and slag is in contact with air and humidity. ${ }^{29,65}$ Sulfurous gases have been measured successfully in the demanding conditions of a tapping area using various instruments. ${ }^{65,66}$

\section{POLYCYCLIC AROMATIC HYDROCARBONS}

Polycyclic aromatic hydrocarbons (PAHs) are a group of organic compounds consisting of molecules containing two or more fused benzene rings, although bicyclic compounds are sometimes included in the term. They are resistant to degradation and regulated as one of the so-called persistent organic pollutants (POPs) ${ }^{67-69}$ Anthropogenic PAH are typically formed by incomplete combustion of organic materials such as oil, wood, or garbage, but all thermal processes containing carbon and hydrogen are potential sources of PAHs. ${ }^{70,71}$ Some PAH compounds are linked to various forms of cancer, and the US Environment Protection Agency (EPA) has identified 16 priority PAHs, based on their potential to induce adverse environmental and health effects. ${ }^{72,73}$ For any occupational health, safety, and environmental (OHSE) purposes, monitoring and reporting guidelines are typically limited to cover these priority substances. In hightemperature processes, however, these substances form in parallel with other organic species and also decompose into lighter species. ${ }^{74-76}$

Industrially, polycyclic aromatic hydrocarbons are generated through combustion reactions or high-temperature processes involving carbonaceous materials. $^{70,76}$ The quantities and characteristics of the PAHs emitted vary greatly and depend on several factors, the most important being the type and amount of organic combustibles burnt. Other important factors are found in the manufacturing process itself and the types of air pollution control devices used. ${ }^{77,78}$ In Mn ferroalloy production, PAH emissions are, for example, generated in the combustion of reductants in the furnace and the baking of electrodes. Airborne PAH emissions from sealed furnaces are largely removed and transferred to the water and sludge in the wet scrubber systems.

In open furnaces, the higher degree of combustion results in lower PAH concentrations in the furnace off-gas. Residual particle-bound compounds may then be collected by the filters, but any remaining gaseous PAH compounds are typically not removed. Depending on the choice of $\mathrm{Hg}$ cleaning method, the PAH levels may be further reduced.
An overview of potential emission points is presented in Table VII. It is commonly known that coal tar pitch is used as a binder in Søderberg electrode paste and further in tamping paste and tap hole clay, although PAH-reduced or PAH-free alternatives are also offered on the market. ${ }^{79}$ Prior to pyrolysis, these materials represent a significant positive development in reducing $\mathrm{PAH}$ dust exposure. During handling of Søderberg paste, dust forms mechanically and may spread in the work environment and beyond, although most likely representing minor amounts of the total PAH emissions from a plant. PAHs may still form, however, through incomplete combustion if, for example, tap hole clay is left burning in the tapping runner after tapping. This loss of clay is a common problem that is often addressed by tap hole maintenance, and may be minimized, e.g., by using sacrificial plates of compressed fiber at the end of the mud gun. ${ }^{80}$

In stack gas from furnace smelting processes, the PAH compounds containing two or three benzene rings are typically gaseous, while those containing more benzene rings are either semivolatile or totally adsorbed on oxide dust or soot particles. The lightest species, naphthalene (boiling point $218^{\circ} \mathrm{C}$ ), will be found in the gas phase even at low temperatures, whereas the larger molecular compounds are liquid or solid and commonly adsorbed on particles. ${ }^{7,81}$ The distribution of compounds between gas and particulate matter is significant to the chemistry of the atmosphere, efficiency of industrial effluent filtration, and human health. ${ }^{70} \mathrm{PAH}$ formation is also linked to soot formation, which in turn is influenced by furnace design and operation. To illustrate the effect of gas temperature, Clarke ${ }^{81}$ reported a 19/81 and 69/31 relative distribution for anthracene and fluoranthene, respectively, sampled at $50^{\circ} \mathrm{C}$.

Separation of gas and particle-bound PAHs is often necessary for inventory calculations. When applying a sampling strategy to separate gas- and condensed-phase PAH, heating of the filter to match the temperature of the gas is crucial to preserve this distribution. In an off-gas duct with a temperature gradient, extractive sampling is only representative of the conditions at the sampling point and cannot be generalized to the entire off-gas. In a gas stream with particulate matter, the fraction of gaseous to particle-bound (chemisorbed/condensed phases) PAHs is a function of temperature as well as PM concentration. Some of the heavier PAHs have boiling points higher than $500^{\circ} \mathrm{C}$, thus making extractive sampling in gaseous form very difficult. ${ }^{82}$ A common approach to circumvent this challenge is to sample the particulates isothermally, then sample the gaseous PAHs downstream of the filter at a lower temperature.

Sampling of PAHs is normally conducted over 3$6 \mathrm{~h}$ to ensure a representative average of the stack gas composition. Where longer sampling intervals 
Table VII. Overview of PAH sources in Mn-ferroalloy smelters

\begin{tabular}{|c|c|c|c|}
\hline $\begin{array}{l}\text { Emission } \\
\text { point }\end{array}$ & Source & Comment & Capture/cleaning \\
\hline $\mathrm{SAF}$ & $\begin{array}{l}\text { Reductants, elec- } \\
\text { trode paste }\end{array}$ & & Furnace off-gas cleaning system \\
\hline $\begin{array}{l}\text { Electrode } \\
\text { loading }\end{array}$ & Søderberg paste & Dust generated by handling of electrode paste & $\begin{array}{l}\text { Diffuse emissions, work environ- } \\
\text { ment. No solution today. }\end{array}$ \\
\hline Tap hole & $\begin{array}{l}\text { Tap hole clay with } \\
\text { organic binder }\end{array}$ & $\begin{array}{c}\text { Baking of tap hole clay. Burning of excess tap } \\
\text { hole clay, typically in the tapping runner } \\
\text { between taps }\end{array}$ & $\begin{array}{c}\text { Diffuse emissions. Smoke/dust } \\
\text { capture in tapping area }\end{array}$ \\
\hline $\begin{array}{l}\text { Tapping } \\
\text { runner }\end{array}$ & $\begin{array}{l}\text { Tamping paste with } \\
\text { organic binder }\end{array}$ & $\begin{array}{c}\text { Depends on baking procedures. Emissions } \\
\text { mainly from fresh tamping paste exposed } \\
\text { to hot slag/metal }\end{array}$ & $\begin{array}{c}\text { Diffuse emissions. Work environ- } \\
\text { ment. Gas/dust capture in tapping } \\
\text { area }\end{array}$ \\
\hline
\end{tabular}

are desirable, the effect of pressure build-up on filters must be considered, as the pressure drop across the filter will alter the sampling flow rate, although there are instruments that can compensate for such effects by using integrated pitot tube velocity readings. Another approach to meet the challenge of high PM and PAH loading is to collect particles and gas into a liquid phase. The particlebound PAHs will then dissolve in the solvent/ absorber, on which total PAH analysis can be conducted. ${ }^{82,83}$

The prevailing standard for sampling of PAHs (ISO 11338-1:2003) proposes three strategies for sampling of PAH from stacks:

- Dilution strategy: water condensation is avoided by dilution of sample gas with filtered/dried/cooled air to avoid water condensation. PAHs are collected on a filter and absorbent.

- Heated filter/condenser/absorber strategy: a heated filter is used to separate particle-bound and gaseous PAHs. Water is removed in a condenser before an absorbent is used to sample gaseous PAHs.

- Cooled probe/adsorber strategy: a lined/inert probe is cooled, and the condensate is collected in a condensate bottle or impinger. Particulate and gaseous $\mathrm{PAH}$ are collected on filters and solid adsorbent.

These methods are assumed to produce identical results, but it is apparent that each of the methods has its own pros and cons. Conditions affecting the performance of the methods are the stack gas temperature, PM loading, and humidity. PAH capture is typically performed either by adsorbent (XAD-2) or absorbent solution (glycol ether). Particle-bound and gaseous PAHs are extracted from filters and adsorbents (for example, by so-called Soxhlet extraction) into a viable organic solvent, which is subsequently analyzed. The analysis of PAHs is normally conducted by gas chromatography with a mass spectrometry detector (for example, Norwegian standard NS 9815). ${ }^{84}$
Table VIII. PAH inventories based on 19 PAHs, dry and corrected for $2 \% \mathrm{CO}_{2}$

\begin{tabular}{|c|c|c|c|}
\hline Year & Furnace product & $\mu \mathrm{g} / \mathrm{dscm}$ & lbs $/ \mathbf{h}$ \\
\hline 2014 & FeMn & 7140 & 4.72 \\
\hline 2014 & SiMn & 118 & 0.063 \\
\hline 2013 & FeMn & 1117 & 0.63 \\
\hline 2013 & SiMn & 94 & 0.055 \\
\hline 2012 & FeMn & 64 & 0.013 \\
\hline $2012^{\mathrm{a}}$ & SiMn & 9030 & 5.08 \\
\hline 2010 & FeMn & 403 & \\
\hline
\end{tabular}

${ }^{\mathrm{a}}$ Calculation based on $20 \mathrm{PAHs}$ (including 2-methylnaphthalene included).

As a response to US EPA information collection requests, the Eramet plant in Marietta, $\mathrm{OH}$ conducted PAH emission inventories for their FeMn and FeSi furnaces. ${ }^{85-88}$ The samples were collected after the baghouse for a FeMn furnace and after the scrubber for a SiMn furnace. The emissions, calculated from $19 \mathrm{PAH}$ components, are presented in Table VIII. The values in this table reveal large variations in the reported emissions for both furnaces.

Measured PAH concentrations in the cleaned offgas of two different, open Mn-producing furnaces are collected in Fig. 3 . Ten of the measurements were on an SAF producing FeMn and four SiMn. There is a general trend of increasing PAHs in the cleaned off-gas with increasing coal in the charge mix. The measured increase is around one order of magnitude, but the data variation is considerable. The measured value at 55\% coal fraction is distinguished, as it is the only charge mix containing woodchips $(<5 \mathrm{wt} . \%)$ and the gas cleaning was done by a baghouse filter. All other measurements were carried out during operation with wet scrubber cleaning. It is also the only dataset not corrected for the $\mathrm{CO}_{2}$ concentration in the off-gas.

It is known from $\mathrm{Si} / \mathrm{FeSi}$ production ${ }^{89}$ that the offgas temperature at the charge top influences the final PAH content, which may partly explain the 


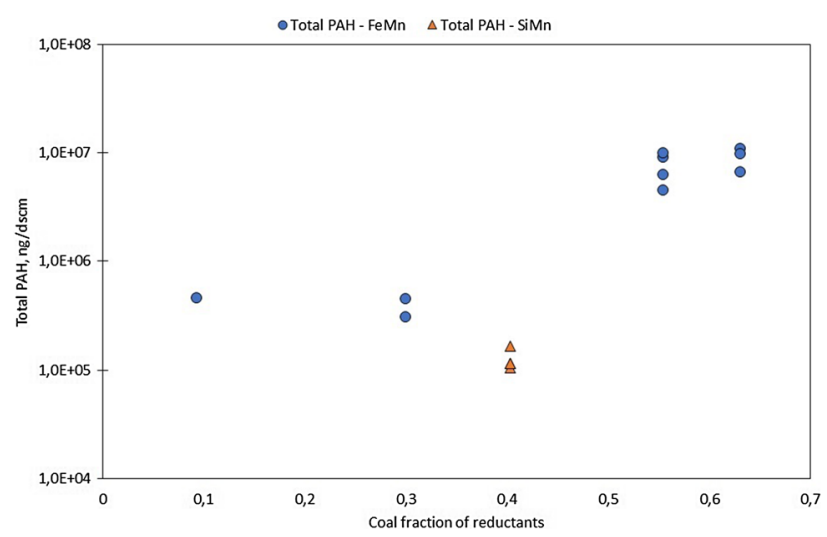

Fig. 3. Measured total PAH emissions from Mn ferroalloy furnaces as a function of the fraction of coal in the charged reductants. ${ }^{85-88}$.

lower total PAH content of the SiMn operation, as higher off-gas temperatures would be expected for SiMn than FeMn. Other possible reasons may be difference(s) in the content of organic compounds in the raw materials and electrode consumption (electrode slipping). Future studies of $\mathrm{PAH}$ emissions should include thorough PAH profile documentation as well as detailed studies on the influence of the operation strategy and raw materials, including the electrode paste. Based on experience from the $\mathrm{Si} /$ FeSi industries, PAH emissions may be partly amended by using adapted operational strategies.

A Norwegian study $^{29}$ of a sealed SAF with Søderberg electrodes showed that the PAH concentration was highest at high power load (MW). This is likely caused by increased coke pyrolysis and electrode consumption at higher furnace loads. In sealed furnaces, the lack of oxygen from air results in incomplete combustion, and thus PAH levels are higher when exiting the SAF than for open furnaces. The gas from sealed furnaces is, however, typically cleaned of most PAHs in the wet scrubbers. Alternatively, the collected off-gases may be burned at a later stage (for example, to recover the energy from the off-gases), and thus the PAHs may be destroyed. ${ }^{74,75,90}$

\section{HEAVY METALS AND TRACE ELEMENTS}

At process temperatures of $1600^{\circ} \mathrm{C}$ or higher, certain metals such as $\mathrm{Zn}, \mathrm{Pb}, \mathrm{Cd}, \mathrm{Na}, \mathrm{Mn}$, and $\mathrm{Fe}$ are gaseous and may escape as metal vapor. As these metal vapors exit the hot zone, however, they may condense on cool surfaces and/or PM. Depending on the temperature profile of the furnace and operating conditions (e.g., off-gas flow profile), the metal vapors may condense on raw materials in the upper, colder parts of the furnace. Smaller particles may exit the furnace with the off-gas and may then be captured by the particulate control systems. If a wet scrubber is used, such particles will largely end up in the sludge. ${ }^{37,41-43}$ Table IX presents typical emissions to air (after abatement) of selected heavy metals, as listed by the IPPC BAT document. ${ }^{91}$

When slag from HC-FeMn production is used as a raw material for $\mathrm{SiMn}$, the $\mathrm{Hg}$ emissions are minimal, as the $\mathrm{Hg}$ has been volatilized and removed in the FeMn furnace process. Similar effects may be achieved for other trace elements which volatilize easily.

Shen et al. ${ }^{43}$ published mass balances for $\mathrm{Zn}$ in FeMn and SiMn production, showing that most Zn exits the furnace in the PM. Other studies $^{37,38,41,43,92}$ showed that there is a significant amount of zinc circulating in the SAF, with a possible negative safety impact. ${ }^{93} \mathrm{Ma}$ et al. ${ }^{63,64}$ studied the distribution of trace elements to alloy, slag, and dust in laboratory-scale liquid melt experiments and pilot-scale SAF experiments. The distribution (except the gas phase) from the pilot furnace is included in Fig. 4. Note that the percentage shown in the figure is the product of the concentration and the mass of each material stream. As the mass of PM is very low compared with the other two phases, elements such as As, S, and $\mathrm{B}$, which appear to have moderate distribution to the PM, may still have significant concentrations in the PM. Ma et al. ${ }^{63,64}$ showed that the distribution of elements in oxidic PM from SiMn production can be correlated to the boiling point of the element and that certain elements may be upconcentrated in the dust, including $\mathrm{Mg}, \mathrm{Li}, \mathrm{Na}, \mathrm{S}, \mathrm{K}, \mathrm{Pb}, \mathrm{Zn}$, and $\mathrm{Al}$.

\section{MERCURY CLEANING}

Mercury $(\mathrm{Hg})$ is something of a special case among the heavy metals, as legislation has long been stringent with respect to $\mathrm{Hg}$ emissions. It is well known that the metal producing industry as a whole contributes significantly to global mercury emissions, through high-temperature treatment of ores and carbonaceous materials, production of coke, and electricity produced by coal-fired power plants. ${ }^{94,95}$ In ferroalloy production, mercury emissions are derived primarily from the manganese ores, although there may be trace amounts in the reductants as well. ${ }^{6,96}$ Back et al. ${ }^{6}$ documented large $\mathrm{Hg}$ variations in manganese ores, with average concentrations of $50 \mu \mathrm{g} / \mathrm{kg}, 1518 \mu \mathrm{g} / \mathrm{kg}$, and $1002 \mu \mathrm{g} / \mathrm{kg}$ for three analyzed smelters, respectively. No overview of the mercury content of various ores was found in literature, and no relevant information on how mercury appears in the main manganese ores. Rytuba, ${ }^{97}$ however, stated that mercury is most likely adsorbed onto manganese and iron oxides, rarely occurring as a separate phase.

Airborne mercury emissions can exist in three forms: gaseous elemental $\left(\mathrm{Hg}^{0}\right)$, gaseous oxidized $\left(\mathrm{Hg}^{2+}\right)$, and particulate $\left(\mathrm{Hg}_{\mathrm{p}}\right){ }^{98-100}$ Some of the mercury in particulate and oxidized forms is captured by the particulate control devices, such as bag 
Table IX. Typical emissions to air $^{91}$

\begin{tabular}{|c|c|c|c|c|c|c|}
\hline (g/ton metal) & $\mathbf{H g}$ & $\mathbf{P b}$ & As & Cd & $\mathbf{C r}$ & $\mathbf{C u}$ \\
\hline HC-FeMn & $0.1-0.15$ & $0.2-0.4$ & 0.02 & 0.005 & 0.02 & 0.08 \\
\hline SiMn & $0.03-0.7$ & $0.2-0.7$ & 0.02 & $0.005-0.1$ & $0.02-1$ & $0.1-0.3$ \\
\hline
\end{tabular}

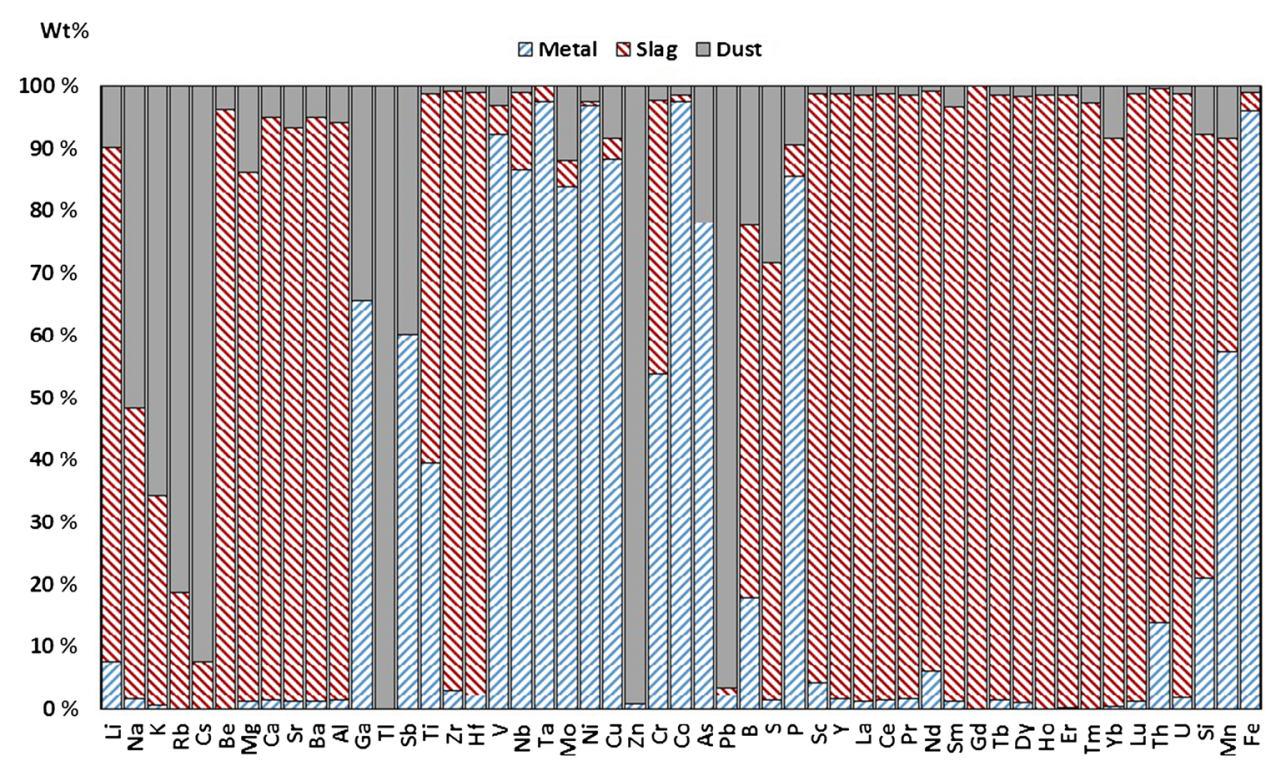

Fig. 4. Distribution of elements in metal, slag, and dust mass flows out of a pilot furnace. Note that the gas phase is not included. Figure reproduced with permission from $\mathrm{Ma}$ et al. ${ }^{64}$.

filters or wet scrubbers. However, the more volatile, elemental mercury will be largely emitted to the atmosphere if no postfurnace gas treatment is applied. Some metallic mercury may be deposited in off-gas systems with wet scrubbers. ${ }^{6}$

There are several different technologies available for $\mathrm{Hg}$ removal from off-gases, including wet scrubbing, dry cleaning with use of Hg-absorbing filters, dry cleaning with injection of active carbon, and filtration on fabric filters. Alternatively, a mercury absorption unit with an activated carbon bed can be installed after an electrostatic filter which removes dust and tars. ${ }^{47}$ In the investigation by Back et al., ${ }^{6}$ the plants were equipped with particle removal devices, such as bag filters and cyclones (i.e., not dedicated to mercury removal, but more generally for air pollution control). It was found that the offgas temperature of the furnace affected the proportion of $\mathrm{Hg}^{0}$ and $\mathrm{Hg}^{2+}$ measured at the outlet of the bag filters, although both $\mathrm{Hg}^{0}$ and $\mathrm{Hg}^{2+}$ are expected to be gaseous at temperatures as low as $140-300^{\circ} \mathrm{C}$. The temperature dependence is also supported by other sources. ${ }^{101-104}$

From available literature, dedicated mercury cleaning appears to be common practice for manganese plants only in Norway. In the early 1990s, Tinfos Jernverk discovered mercury emissions, and developed a process for off-gas cleaning. Eramet Norway followed but opted for a different technology, and Vale Manganese Norway chose yet a third strategy. At Tinfos Jernverk (now Eramet Norway Kvinesdal), the furnace off-gas is burned in overstoichiometric conditions to recover the energy using a steam boiler. The $\mathrm{Hg}$ content of the combusted off-gas is around $280 \mu \mathrm{g} / \mathrm{Nm}^{3}$. The off-gas is volumetrically expanded by the combustion, and then treated in a co-current washing process in a limestone bed. The washing fluid is a solution of sodium hypochlorite $(\mathrm{NaClO})$ and water (typically sea water, but fresh water has been tried successfully). The mercury is reacted into $\mathrm{HgCl}_{2}$. The cleaned off-gas is let out into the air, while the water is pumped into a precipitation tank, where $\mathrm{HgCl}_{2}$ reacts with $\mathrm{Na}_{2} \mathrm{~S}$ to form $\mathrm{HgS}$ (and $\mathrm{NaCl}$ ). The water is then filtered and analyzed to confirm that the mercury is in the form of HgS. The filter product is classified as hazardous waste and deposited. The filtrate, containing $<0.5 \mu \mathrm{g} / \mathrm{l}$ mercury, is recirculated. Mercury emissions are reported to be reduced by $94 \%$ when using this method. ${ }^{47,96}$

Eramet Norway, on the other hand, selected an electrostatic precipitation unit which removes the residual dust and tars. The cleaning is performed on 
the furnace gas from a sealed SAF, i.e., with high content of $\mathrm{CO}(\mathrm{g})$. The gas is then heated to the reaction temperature $\left(60-85^{\circ} \mathrm{C}\right)$ before flowing through a packed bed of activated carbon impregnated with elemental sulfur. The sorption process is temperature dependent; if the reaction temperature is too low, moisture may condensate in the packed bed and reaction rates are slow. At higher temperatures, loss of sulfur is a risk. Metallic $\mathrm{Hg}(\mathrm{g})$ is adsorbed and fixated by reaction with sulfur to form HgS. ${ }^{105}$ The adsorber material is replaced regularly and deposited in a secure landfill. The cleaning efficiency is estimated to be $98 \% .47,96$

A third approach is adapted at what is now Ferroglobe Mangan Norge (previously Glencore Manganese Norway and before that Vale Manganese Norway), where they largely base their production on sinter feed produced at the plant. The off-gas from the sinter plant is cleaned by injection of active carbon into the off-gas channel, upstream of the particle emission control. The activated carbon contains approximately $0.5-0.6 \%$ sulfur, which increases removal of both dioxins and mercury. ${ }^{106}$ The mercury is adsorbed on the active carbon particles and is stabilized by reaction to $\mathrm{HgS}$. This is a method used for mercury cleaning from municipal and hazardous-waste incinerators ${ }^{51}$ and coal-fired thermal power plants. ${ }^{107}$ Other methods of mercury cleaning include the Boliden Norzink process, selenium filter (Boliden Contech), and the Medisorbon process (Lurgi Bamag). ${ }^{96,108,109}$

\section{AIRBORNE PARTICULATE MATTER (PM)}

Davourie et al. ${ }^{30}$ estimated the contribution to total direct and indirect PM emissions generated in different process stages, as presented in Table X. Their LCA is based on data from eight smelters with different furnace types and emission control systems. These tabulated results indicate that the furnace process is typically the main source of PM in primary Mn ferroalloy smelters. Ghorpade reported in $2007^{31}$ that off-gas from an open furnace contained approximately $1.9 \mathrm{~g} / \mathrm{Nm}^{3} \mathrm{PM}$, measured before the baghouse filters, and that after cleaning, the content of suspended PM was $10-15 \mathrm{mg} / \mathrm{Nm}^{3}$, but EU IPPC BAT reports that best practice for

Table X. Estimated contribution of processes to total PM emissions ${ }^{30}$

\begin{tabular}{lcc}
\hline Process step & & $\begin{array}{c}\text { Contribution } \\
(\%)\end{array}$ \\
\cline { 1 - 2 } Extraction etc. & 34 \\
Furnter production & 7 \\
Refining smelting & 30 \\
Tapping, casting, crushing, screen- & 5 \\
ing & 13 \\
Other smelter processes & 8 \\
\hline
\end{tabular}

baghouse filters results in clean gas concentrations of $5 \mathrm{mg} / \mathrm{Nm}^{3}$. For sealed furnaces with cascade wet scrubbers, clean gas PM emissions are below 10$40 \mathrm{mg} / \mathrm{Nm}^{3}{ }^{91}$

Thermally generated PM is often referred to as fume. All process steps where liquid metal comes into contact with oxygen (air) generate fume; this includes tapping, refining, and casting. PM formed at ambient temperature, on the other hand, is typically generated mechanically, and sources include handling of raw materials and products in, for example, packing stations, crushers, screens, and transports. The total mass of airborne particles has been estimated for the whole lifecycle of the products. On average, $9.6 \mathrm{~g} \mathrm{PM}$ is generated per $\mathrm{kg}$ of manganese ferroalloy produced. For refined FeMn, HC-FeMn, and SiMn, the amount of PM is $8.0 \mathrm{~g}, 8.5 \mathrm{~g}$, and $11.5 \mathrm{~g}$, respectively. ${ }^{3,45}$

The MOR produces PM at high temperatures and turbulent conditions. Turbulence is known to generate PM through droplet expulsion or splashing, ${ }^{110}$ but according to Yamamoto et al. ${ }^{111,112}$ and Lee and Kolbeinsen, ${ }^{113}$ the main fume formation mechanism is vaporization and oxidation. ${ }^{110,114,115}$ This active oxidation fume generation mechanism has also been described by others. ${ }^{63,116-118}$ For ferromanganese (FeMn), the fume generation is dominated by the relatively high vapor pressure of $\mathrm{Mn}$. The fume is mostly composed of metallic oxides, and as $\mathrm{Mn}$ is a transition metal, the PM may consist of different oxides. ${ }^{117}$ The type of oxide (oxidation state of $\mathrm{Mn}$ ) is important with respect to solubility and bioaccessibility. ${ }^{119,120}$ Industrial dust from $\mathrm{Mn}$ ferroalloy production has been studied by a number of authors, and the reported characteristics vary significantly. Nonetheless, $\mathrm{Mn}_{3} \mathrm{O}_{4}$ seems to be a major component of industrial FeMn dust. ${ }^{121-124}$

For silicomanganese (SiMn), the fuming processes are more complex than for FeMn. The effect of alloying Si with Mn results in two oxidation mechanisms operating in parallel. Si oxidizes through a two-step reaction without vaporization. ${ }^{125-127}$ The $\mathrm{Mn}$ vaporization is active simultaneously, and $\mathrm{SiO}$ (g) interacts with $\mathrm{Mn}(\mathrm{g})$ in a complex, temperaturedependent manner, postulated by Ma et al. ${ }^{116}$ The differences between fuming from FeMn and SiMn is highlighted by the effect of humidity. Certain FeMn smelters have successfully implemented a dustsuppression technology during casting, where an atomized water mist is sprayed around the casting beds. ${ }^{123,128-130}$ This water vapor effect has been reproduced in laboratory-scale experiments. For SiMn, however, the vapor had no effect at temperatures higher than $1450^{\circ} \mathrm{C} .^{131,132}$

According to scanning electron microscopy (SEM) analysis of workplace aerosols collected from $\mathrm{HC}$ FeMn tapping and of SiMn casting, the PM occurs as agglomerates, either chain-like or compact, while samples from the MOR process can be individual particles. ${ }^{121}$ Gunst et al. ${ }^{122}$ described the PM from the MOR and tapping area as "slag particles." 
Table XI. Mass concentrations of particle-bound Mn measured at stationary sites outside the smelter fence line

\begin{tabular}{|c|c|c|c|c|c|}
\hline $\begin{array}{l}\text { Location } \\
\text { and Ref. }\end{array}$ & $\begin{array}{l}\text { Distance } \\
(\mathbf{k m})\end{array}$ & $\underset{\left(\mu \mathbf{g} / \mathbf{m}^{3}\right)}{\operatorname{Mn} \text { in } \mathbf{P M}_{10}}$ & $\underset{\left(\mu \mathbf{g} / \mathbf{m}^{3}\right)}{\operatorname{Mn} \operatorname{in}} \mathbf{P M}_{2.5}$ & $\begin{array}{l}\text { Average } \\
\text { time }\end{array}$ & Methods \\
\hline Spain $^{147}$ & 0.1 & 0.670 & & $\leq 1$ week & $\begin{array}{l}\text { Low- and high-volume samplers; ICP-MS, } \\
\text { SEM-EDX, XRD }\end{array}$ \\
\hline Spain $^{144}$ & 0.4 & & 0.781 & 15 months & $\begin{array}{c}\text { High-volume sampler; ICP-AES, ICP-MS, } \\
\text { SEM }\end{array}$ \\
\hline Spain $^{147}$ & 0.6 & 0.232 & & $\leq 1$ week & $\begin{array}{l}\text { Low- and high-volume samplers; ICP-MS, } \\
\text { SEM-EDX, XRD }\end{array}$ \\
\hline France $^{148}$ & 0.8 & & 0.199 & 3 weeks & Impactor; ICP-EAS, ICP-MS \\
\hline Spain $^{149}$ & 1.5 & & 0.118 & 1 year & Low-volume sampler; ICP-MS \\
\hline France $^{150}$ & 2.0 & 0.147 & & 2 years & $\begin{array}{c}\text { High-volume sampler; ICP-AES, ICP-MS, } \\
\text { ICP-MS-DRC }\end{array}$ \\
\hline Spain $^{144}$ & 5.0 & 0.166 & 0.077 & 15 months & $\begin{array}{c}\text { High-volume sampler; ICP-AES, ICP-MS, } \\
\text { SEM }\end{array}$ \\
\hline $\mathrm{USA}^{151}$ & 8.0 & & 0.011 & 3 months & Impactor; ICP-MS \\
\hline Spain $^{144}$ & 20 & 0.029 & & 15 months & $\begin{array}{l}\text { High-volume sampler; ICP-AES, ICP-MS, } \\
\text { SEM }\end{array}$ \\
\hline Spain $^{149}$ & 20 & & 0.018 & 1 year & Low-volume sampler; ICP-MS \\
\hline Spain ${ }^{149}$ & 25 & & 0.022 & 1 year & Low-volume sampler; ICP-MS \\
\hline
\end{tabular}

Optical instruments can be used for measuring particle concentration in real time with direct reading and data logging. ${ }^{133}$ Laser-based sensors have been successfully tested in the industrial conditions of Mn ferroalloy industry and found to be applicable for long-term PM monitoring and evaluation of dust-reducing efforts. However, the accuracy of the instruments is dependent on sitespecific calibration ${ }^{16,134-137}$ For research studies where number-based concentration measurements are required (as opposed to the more common mass concentration measurements), other instruments such as the electrical low-pressure impactor (ELPI by Dekati Ltd.) and scanning mobility particle sizer (SMPS by TSI Inc.) may be used. Both have been successfully applied in the $\mathrm{Mn}$ ferroalloy industry. ${ }^{138-141}$

\section{AIR QUALITY MEASUREMENTS}

Air quality measurements in the ambient atmosphere near $\mathrm{Mn}$ ferroalloy plants focus on the physiochemical characteristics of dust (PM). Air quality concentration norms exist for most emission types discussed in this paper, and they vary somewhat between countries. This section discusses air quality studies focused on particle-bound $\mathrm{Mn}$ in the vicinity of plants, and outside fence lines. Currently, norms for Mn concentrations in PM normally exist at guideline level. The World Health Organization (WHO) suggests an annual average norm of $150 \mathrm{ng} /$ $\mathrm{m}^{3}$ for $\mathrm{PM}_{10}{ }^{142}$ This level may be compared with the values measured in the vicinity of Mn ferroalloy smelters presented in Table XI (the most recent reference is given for each location; see references within these publications for details and previous measurements). Mn concentrations are typically measured in $\mathrm{PM}_{10}$ and $\mathrm{PM}_{2.5}$, but $\mathrm{Mn}$ may also be present in higher size fractions. ${ }^{143}$ The Mn concentrations are typically inversely correlated with distance from the plant, a trend which is readily seen in Table XI. Although stipulated to 1 year by the WHO, the trend in the data in this table is strong in spite of the highly variable averaging times. It is also noteworthy that the Mn concentrations in $\mathrm{PM}_{10}$ and $\mathrm{PM}_{2.5}$ are on the same order of magnitude at comparable distances from the source. Meteorology and topography effects can, however, influence the concentration trends and have a significant impact on human and environmental exposure. Moreno et al. ${ }^{144}$ reported, for example, how a coastal wind system can influence and recycle the exposure effect of industrial dust plumes. Industry emission control guidelines which consider the effect of meteorology are applied only in Denmark. ${ }^{145,146}$

Mn characterization requires sampling of PM followed by chemical analysis, and has been done by various methods including collection from horizontal surfaces indoors and outdoors, ${ }^{152-154}$ personal sampling equipment carried by subjects living around the plant, ${ }^{151,155,156}$ atmospheric deposition directly into collection receptors (EN15841:2009), or indirectly by biomonitoring in moss. ${ }^{143,157}$ Stationary sampling using high- or low-volume air pumps, with impactors or filters, is also very common. The low-cost advantage of deposition sampling compared with air sampling has normally resulted in a higher spatial density of sampling points around a plant in deposition studies. Thus, these are particularly valuable for identifying sources or obtaining a spatial picture of environmental impacts. Specifically, this is true for analysis of metals including Mn. ${ }^{158}$ The main disadvantages of deposition and/or filter sampling with 
postlaboratory analysis is cost and the fact that the PM is collected over relatively extended periods of time, which convolutes sources and the time variations needed for source identification. Current trends in air quality studies include the use of low-cost online instruments for PM, e.g., micro sensing units (MSUs) with real-time instruments for chemical analysis, real-time analysis software, and concurrent use of weather stations. ${ }^{159-162}$

A study in Cantabria in Spain showed that Mn levels were above normal at about $1.5 \mathrm{~km}$ away from the plant, but the Mn detected further away was not from the smelter. ${ }^{149}$ Another study in Cantabria ${ }^{147}$ described the physiochemical characteristics of $\mathrm{PM}_{10}$ and deposition samples close to the plant. Results showed that $60 \%$ of the particles in the air-sampled $\mathrm{PM}_{10}$ fraction were spheres and the source was most likely the thermal processes (fume) discussed in the previous section of this article. In the deposited dust samples, particles with $\mathrm{Mn}$ content were coarse and of irregular shape. These particles were attributed to raw material and product handling and processing.

The Val Camonica Valley in Italy has been extensively studied following the closure of three ferroalloy factories operating there between 1950 and 1995. A decade after closure, researchers found that Mn levels in soil and indoor-settled dust were significantly elevated within $0.5 \mathrm{~km}$ of the latest plant to close down. ${ }^{154,156}$ Another study compared the Val Camonica area with an active ferroalloy plant, finding that $\mathrm{Mn}$ levels were inversely related to the distance to the active plant but the same was not observed at the sites with historic Mn production. They also confirmed correlations between $\mathrm{Mn}$ in dust, soil, and air (indoor and outdoor dust) concentrations, as well as human exposure biomarkers. ${ }^{153}$

In Montreal, Canada, an extensive Mn concentration study showed a $50 \%$ reduction, 8 years after a Mn plant closure $25 \mathrm{~km}$ outside the city. They also reported correlations between $\mathrm{Mn}$ concentrations and traffic, linked to an additive used in Canadian gasoline. ${ }^{163}$ Observations from the area of and around two FeMn smelters near Dunkerque in France indicated that the industrial emissions contained more ultrafine aerosols and a higher proportion of metal-bearing particles than the background air upwind of the plant. Particles evolve fast during their transport from the chimney to the downwind sampling sites, by adsorption of co-emitted volatile organic compounds (gas) and sulfuric acid, but also by agglomeration with preexisting particles. ${ }^{148,150,164}$

\section{CONCLUSION AND IDENTIFIED RESEARCH NEEDS}

During the compilation of this literature review, a number of knowledge gaps and research needs have been identified. No open literature has, for example, been found on fume generation during the industrial refining (MOR) process, despite it being a rather well-known source of diffuse PM emissions. The lack of literature describing the formation mechanism of $\mathrm{NO}_{x}, \mathrm{SO}_{x}$, and $\mathrm{H}_{2} \mathrm{~S}$ during $\mathrm{Mn}$ production was equally unexpected, as $\mathrm{SO}_{x}$ emissions are well known in this industry. Additionally, no overview of the mercury content of commercially available ores was found in the literature, and no relevant information on the form in which mercury appears in common ores.

There is also very little information on PAH emissions from Mn ferroalloy production. Although it is reasonable to assume some similarities to aluminum and steel production, where carbonaceous reductants and electrodes are used, there is an obvious lack of branch-specific information in the open literature. We, the authors of this literature review, recommend that these gaps be filled, and hope that this overview may contribute to the initialization of new studies on these topics.

\section{ACKNOWLEDGEMENTS}

This article was enabled through funding from the Research Council of Norway through the center for research-driven innovation (SFI) Metal Production (Grant No. 237738). Mr. E. Barstad made one of the figures. The authors wish to thank Prof. G. Tranell at the Norwegian University of Science and Technology, Mr. G.O. Storheil at Ferroglobe Mangan Norge, and Dr. B. Ravary and Dr. M. Kadkhodabeigi at Eramet Norway AS for comments and discussions.

\section{OPEN ACCESS}

This article is distributed under the terms of the Creative Commons Attribution 4.0 International License (http://creativecommons.org/licenses/by/4.0/ ), which permits unrestricted use, distribution, and reproduction in any medium, provided you give appropriate credit to the original author(s) and the source, provide a link to the Creative Commons license, and indicate if changes were made.

\section{REFERENCES}

1. G.M. Bedinger, L.A. Corathers, P.H. Kuck, J.F. Papp, D.E. Polyak, E.K. Schnebele, K.B. Shedd, C.A. Tuck, Report, U.S. Department of the Interior, U.S. Geological Survey (2014).

2. S.E. Olsen, M. Tangstad, and T. Lindstad, Production of Manganese Ferroalloys (Trondheim: Tapir Academic, 2007).

3. M. Postle, T. Nwaogu, S. Upson, C. Clark, and A. Heinewetter, Report, International Manganese Institute (2015).

4. L.A. Corathers, Report, U.S. Department of the Interior, U.S. Geological Survey (2014).

5. M. Gasik, Handbook of Ferroalloys: Theory and Technology (Oxford: Butterworth-Heinemann, 2013).

6. S.-K. Back, J.-H. Sung, Y.-H. Moon, Y.-H. Kim, K.-S. Seok, G.-J. Song, and Y.-C. Seo, Environ. Pollut. 227, 357 (2017).

7. M. Tangstad, K. Ichihara, and E. Ringdalen, Pretreatment unit in ferromanganese production, in INFACON XIV (Kyiv, Ukraine, 2015). 
8. P. Pienaar and W. Smith, A case study of the production of high-grade manganese sinter from low-grade Mamatwan manganese ore, in INFACON VI (SAIMM, Johannesburg, 1992), p. 131.

9. J. Daavittila, H. Krogerus, P. Oikarinen, and R. Sarkkinen, Sintered manganese ore and its use in ferromanganese production, in INFACON IX (The Ferroalloys Association, Quebec City, 2001).

10. M. Tangstad, eds., Metal Production in Norway (Trondheim: Akademika, 2013).

11. E. Dominguez, Pelletizing Mn ore fines at Icomi, Brazil, in Second International Symposium on Agglomeration (American Institute of Mining, Metallurgical and Petroleum Engineers, 1977).

12. G.H. Crouch, E.C. Dominguez, and C.R. Schumacher, Method for producing manganese oxide pellets, in USPTO, USPTO Assignment, Espacenet (Bethlehem Steel Corporation, USA, 1975).

13. D.-Q. Zhu, W. Yu, X.-L. Zhou, and J. Pan, J. Central South Univ. 21, 3485 (2014).

14. S.E. Olsen, Report No. SINTEF A12384, SINTEF, Norway (2009).

15. L.R. Nelson, Evolution of the mega-scale in ferro-alloy electric furnace smelting, in TMS 143th Annual Meeting \& Exhibition (Springer, San Diego, CA, 2014).

16. S. Grådahl, S. Johansen, B. Ravary, B. Andresen, and H. Tveit. Reduction of emissions from ferroalloy furnaces, in INFACON XI (MacMillan, New Delhi, 2007).

17. S. Gullikstad Johnsen, M. Ksiazek, S. Andersson, and B. Panjwani, Report No. F27650, SINTEF Materials and Chemistry (2016).

18. M. Ksiazek, T. Maik, E. Ringdalen, and M. Tangstad. The thermal diffusivity of raw materials for ferromanganese production, in INFACON (Almaty, Kazakhstan, 2013).

19. S. Gunasekaran and G. Anbalagan, Bull. Mater. Sci. 30, 339 (2007).

20. R. Ishak and M. Tangstad, in INFACON XI (2007), p. 268.

21. J.D. Steenkamp, C.J. Hockaday, J.P. Gous, and T.W. Nzima, JOM 69, 1712 (2017).

22. B.-D. You, K.-Y. Park, J.-J. Pak, and J.-W. Han, Met. Mater. 5, 395 (1999).

23. P.J. Jonker, Hot gas cleaning of furnace off-gases, in $I N$ FACON XIII (Almaty, Kazakhstan, 2013).

24. E.S. Schubert and R. Gottschling, Co-generation: a challenge for furnace off-gas cleaning systems, in Southern African Pyrometallurgy International Conference (The Southern African Institute of Mining and Metallurgy, Johannesburg, 2011.

25. L. Holappa and J.S. Afr, Inst. Min. Metall. 110, 703 (2010).

26. I.T. Kero, H. Dalaker, S. Fosse Håkonsen, and R. Khalil, Report No. 2018:00171, SINTEF (2018).

27. B. Wittgens, B. Panjwani, T. Pettersen, R. Jensen, B. Ravary, and D.-O. Hjernes, SCORE: staged combustion for energy recovery in ferro-alloy industries-experimental validation, in INFACON XV (Southern African Institute of Mining and Metallurgy (SAIMM), Cape Town, 2018).

28. A. Bandyopadhyay, Clean Technol. Environ. Policy 13, 421 (2011).

29. S. Grådahl and T. Vassbotn, Report No. STF24 F02601, SINTEF, Trondheim, Norway (2002).

30. J. Davourie, L. Westfall, M. Ali, and D. McGough, Neurotoxicology 58, 180 (2017).

31. S.Y. Ghorpade, Strategic plan to abate pollution and to beneficiate low grade manganese ore at Smiore's metal and ferroalloys plant, in INFACON VII (FFF, Trondheim, Norway, 1995).

32. M. Kadkhodabeigi, B. Ravary, and D.O. Hjertenes, Modeling of off-gas and particles flow under the roof of a closed submerged arc furnace, in INFACON XIV, Kiev, Ukraine (2015).

33. L. Harris, J. Air Pollut. Control Assoc. 15, 302 (1965).

34. A. Lømo, Pollution problems with electric reduction furnaces in the ferro-alloy industry, in INFACON (South
African Institute of Mining and Metallurgy, Johannesburg, 1975), p. 251.

35. E. Eriksen and A. Lømo, Pollution control and energy recovery in the ferroalloy industry, in Extraction Metallurgy ' 85 (The Institute of Mining and Metallurgy, London, 1985), p. 445.

36. B. Ravary, L. Hunsbedt, and O. Kristensen, Progress in recycling sludge from off-gas cleaning of manganese alloy furnaces, in INFACON XIII (Almaty, Kazakhstan, 2013).

37. R. Shen, G. Zhang, M. Dell'Amico, P. Brown, and O. Ostrovski, A feasibility study of recycling of manganese furnace dust, in INFACON XI (New Delhi, India, 2007).

38. T. Hamano, G. Zhang, P. Brown, and O. Ostrovski, ISIJ Int. 48, 906 (2008).

39. H. Dalaker and K.E. Ekstrøm, Recovery of manganese from sludge through reduction with spent pot lining from aluminium industry, in INFACON XV (Southern African Institute of Mining and Metallurgy (SAIMM), Cape Town, 2018).

40. B. Ravary, L. Hunsbedt, D. Haaland, and O.T. Nilsen, Industrial pilot for sludge recycling, in INFACON $X V$ (Southern African Institute of Mining and Metallurgy (SAIMM), Cape Town, 2018).

41. D. Slizovskiy and M. Tangstad. The effect of potassium and zinc circulation on agglomeration of a charge in SAF, in INFACON XII (Helsinki, Finland, 2010).

42. S. Gaal, M. Tangstad, and B. Ravary, Recycling of waste materials from the production of FeMn and SiMn. in $I N$ FACON XII - Sustainable Future Symposium (Helsinki, Finland, 2010).

43. R. Shen, G. Zhang, M. Dell'Amico, P. Brown, and O. Ostrovski, ISIJ Int. 45, 1248 (2005).

44. L.A. Westfall, J. Davourie, M. Ali, and D. McGough, Int. J. Life Cycle Assess. 21, 1573 (2016).

45. B. Klocok and D. McGough, Report No., International Manganese Institute, Hatch Ltd. (2014).

46. S. Eggleston, L. Buendia, K. MIwa, T. Ngara, and K. Tanabe, eds. industrial processes and product use, in 2006 IPCC Guidelines for National Greenhouse Gas Inventories, ed. The Intergovernmental Panel on Climate Change $(I P C C)$, vol 3 (Institute for Global Environmental Strategies (IGES), Hayama, 2006).

47. L. Hunsbedt, P. Cowx, R. Flatabø, K. Johansen, and J. Bustnes, Environmental challenges for Norwegian Mn-industry, in INFACON XI (11th International Congress on Ferroalloys) (MacMillan, New Delhi, 2007).

48. N. Haque and T. Norgate, J. Clean. Prod. 39, 220 (2013).

49. T. Lindstad, S. Olsen, G. Tranell, T. Færden, and J. Lubetsky, Greenhouse gas emissions from ferroalloy production, in INFACON XI (New Delhi, India, 2007).

50. I.J. Eikeland, B. Monsen, and I.S. Modahl. Reducing $\mathrm{CO} 2$ emissions in Norwegian ferroalloy production, in Greenhouse Gases in the Metallurgical Industries: Policies, Abatement and Treatment (Met. Soc. CIM, Toronto, 2001).

51. S. Chen, M. Rostam-Abadi, and R. Chang, Am. Chem. Soc. Div. Fuel Chem. 41, 442 (1996).

52. M. Sjardin, Report No., Copernicus Institute, University of Utrecht, T.A.S. Department of Science, Utrecht, The Netherlands (2003).

53. T. Lindstad, B. Monsen, and K.S. Osen, How the ferroalloy industry can meet greenhouse gas regulations, in $I N$ FACON XII (Outotec Oyj, Helsinki, 2010).

54. N.E. Kamfjord, Mass and energy balances of the silicon process-improved emission standards, in Materials Science and Engineering (The Norwegian University of Science and Technology, Trondheim, 2012).

55. I. Kero, S. Grådahl, and G. Tranell, Emissions from MG-Si/ FeSi production-a summary, in Silicon for the Chemical and Solar Industry XIII (The Norwegian University of Science and Technology (NTNU), Kristiansand, 2016).

56. N. De Nevers, Air Pollution Control Engineering (Long Grove: Waveland, 2010).

57. E. Chan, M. Riley, M.J. Thomson, and E. Evenson, ISIJ Int. 44, 429 (2004). 
58. Echterhof, T. and H. Pfeifer, ISIJ Int., 51(10), 1631 (2011).

59. T. Echterhof and H. Pfeifer, Metall. Mater. Trans. B 43, 163 (2012).

60. M. Kirschen, L. Voj, and H. Pfeifer, Clean Technol. Environ. Policy 7, 236 (2005).

61. E.H. Myrhaug, H. Tveit, N.E. Kamfjord, G.J. Andersen, and G. Aslaug, NOx emissions from silicon production, in Silicon for the Chemical and Solar Industry XI (Fagtrykk AS/The Norwegian University of Science and Technology, Bergen-Ulvik, 2012).

62. H. Saridikmen, C.S. Kucukkaragoz, and R.H. Eric, Sulphur behaviour in ferromanganese smelting, in INFACON $X I$ - International Ferroalloy Congress (MacMillan \& The Indian Ferroalloy Producers' Association, New Delhi, 2007).

63. Y. Ma, I. Kero, S.J.F. Gates, and G. Tranell, Trace elements behavior during the oxidation of liquid SiMn alloy, in 8th International Symposium on High-Temperature Metallurgical Processing (Springer, 2017).

64. Y. Ma, E. Moosavi-Khoonsari, I. Kero, and G. Tranell, Accepted for publication in Metall. Mater. Trans. B (2018). https://doi.org/10.1007/s11663-018-1358-9.

65. B. Ravary and S. Grådahl, Improving environment in the tapping area of a ferromanganese furnace, in INFACON XII (Helsinki, Finland, 2010).

66. T.A. Aarhaug, A. Ferber, O. Kjos, and E. Ringdalen. Online gas characterization by advanced spectrometry, in INFACON XIII (Almaty, Kazakhstan, 2013).

67. G.C. Bandeira and H.E. Meneses, eds., Handbook of Polycyclic Aromatic Hydrocarbons-Chemistry, Occurrence and Health Issues. Chemistry Research and Applications (New York: Nova Science, 2013).

68. K. Breivik, V. Vestreng, O. Rozovskaya, and J.M. Pacyna, Environ. Sci. Policy 9, 663 (2006).

69. Y. Zhang and S. Tao, Atmos. Environ. 43, 812 (2009).

70. H.I. Abdel-Shafy and M.S.M. Mansour, Egypt. Petrol. Res. Inst. 25, 107 (2016).

71. A. Björseth and T. Ramdahl, Handbook of Polycyclic Aromatic Hydrocarbons, Volume 2, Emission Sources and Recent Progress in Analytical Chemistry (New York, NY: Marcel Dekker, 1985).

72. K. Ravindra, R. Sokhi, and R. Van Grieken, Atmos. Environ. 42, 2895 (2008).

73. K.-H. Kim, S.A. Jahan, E. Kabir, and R.J. Brown, Environ. Int. 60, 71 (2013).

74. B. Panjwani, S. Andersson, B. Wittgens, and J.E. Olsen, Cleaning of polycyclic aromatic hydrocarbons (PAH) obtained from ferroalloys plant, in 12th International Conference on Computational Fluid Dynamics in the Oil \& Gas, Metallurgical and Process Industries (SINTEF, Trondheim, 2017).

75. S. Andersson, Report No. F23882, SINTEF Materials and Chemistry, D.o.P. Technology (2013).

76. ELPIviTM Software Manual version 4.10. (Dekati Ltd, Tampere, 2008).

77. H.-H. Yang, S.-O. Lai, L.-T. Hsieh, H.-J. Hsueh, and T.-W. Chi, Chemosphere 48, 1061 (2002).

78. H.-H. Yang, W.-J. Lee, S.-J. Chen, and S.-O. Lai, J. Hazard. Mater. 60, 159 (1998).

79. T. Eidet and $\varnothing$. Mikkelsen, PAH-free binders in metallurgical carbon pastes, in INFACON XV (Southern African Institute of Mining and Metallurgy (SAIMM), Cape Town, 2018).

80. J. Steenkamp, J. Sutherland, D. Hayman, and J. Muller, JOM 68, 1547 (2016).

81. A.G. Clarke, eds., Industrial Air Pollution Monitoring (Berlin: Springer, 2012).

82. H. Gaertner, T.A. Aarhaug, B. Wittgens, J.C. Fjelldal, M. Legård, and G. Tranell, Measurements of PAH emissions in the ferroalloy industry, in INFACON XV (Southern African Institute of Mining and Metallurgy (SAIMM), Cape Town, 2018).

83. O.S. Kjos, T.A. Aarhaug, B. Wittgens, and A. Brunsvik, Atline analysis of polycyclic aromatic hydrocarbons in alu- minium primary production.Light Metals, ed. J. Grandfield (San Diego, CA: Springer, 2014), p. 541.

84. T.A. Aarhaug, A. Ferber, and H. Gaertner, In-situ spectroscopy in the ferroalloy industry, in INFACON $X V$ (Southern African Institute of Mining and Metallurgy (SAIMM), Cape Town, 2018).

85. I. Environmental Quality Management, Report No. PN: 050352.0022, Eramet Marietta Inc., E.M. Inc. (Cincinnati/ Marietta, OH, 2010)

86. I. Environmental Quality Management, Report No. EQ PN: 050352.0028, Eramet Marietta Inc., I. Environmental Quality Management (Cincinatti/Marietta, OH, 2013).

87. I. Environmental Quality Management, Report No. EQ PN: 050352.0031, Eramet Marietta Inc., E.M. Inc. (Cincinatti/ Marietta, OH, 2014).

88. B. Nelson, Ferroalloys 2013 Test Report Review. (Bradley Nelson EC/R Inc., 2013).

89. I.T. Kero, S. Grådahl, and G. Tranell, J. Met. (JOM) 69, 365 (2017).

90. B. Panjwani, B. Wittgens, S. Andersson, B. Ravary, E. Myrhaug, and M. Kadkhodabeigi, Design and sizing of combustion chamber for energy recovery and oxidation of polycyclic aromatic hydrocarbons (PAH), in INFACON XV (Southern African Institute of Mining and Metallurgy (SAIMM), Cape Town, 2018)

91. Best Available Techniques (BAT) Reference document for the non-ferrous metals industries (Integrated Pollution Prevention and Control (IPPC), 2014).

92. Y.E. Lee and D.S. Kozak, The role of zinc in the eruption of high carbon FeMn smelting furnace, in Electric Furnace Conference (1993)

93. G. Pochart, L. Joncourt, N. Touchard, and C. Perdon. Metallurgical benefit of reactive high grade ore in manganese alloys manufacturing, in INFACON XI (New Delhi, India, 2007).

94. J. Munthe and M. Goodsite, eds., Where Does Mercury in the Arctic Environment Come From, and How Does It Get there? (Oslo: Arctic Monitoring and Assessment Programme (AMAP), 2011), p. 9.

95. E.G. Pacyna, J. Pacyna, K. Sundseth, J. Munthe, K. Kindbom, S. Wilson, F. Steenhuisen, and P. Maxson, Atmos. Environ. 44, 2487 (2010).

96. D. Haaland, M. Bruno, and T. Thomassen, Mercury removal from off-gases at tinfos manganese plante, Øye Smelteverk, Norway, in INFACON IX-The Ninth International Ferroalloys Congress (The Ferroalloys Association, Washington, 2001).

97. J.J. Rytuba, Environ. Geol. 43, 326 (2003).

98. D.L. Laudal, J.H. Pavlish, J. Graves, and D. Stockdill, J. Air Waste Manag. Assoc. 50, 1798 (2000).

99. J. Li, B. Chen, G. Chen, W. Wei, X. Wang, J. Ge, K. Dong, H. Xia, and X. Xia, J. Clean. Prod. 140, 1470 (2017).

100. T.L. Mlakar, M. Horvat, T. Vuk, A. Stergaršek, J. Kotnik, J. Tratnik, and V. Fajon, Fuel 89, 1936 (2010).

101. V. Bansal, R.W. Taylor, P. Maly, and B. Yetter, Enhanced capture of mercury in baghouse by using novel filtration media and filter design, in Cement Industry Technical Conference, 2012 IEEE-IAS / PCA 53rd (IEEE, 2012).

102. J. Jurng, T.G. Lee, G.W. Lee, S.-J. Lee, B.H. Kim, and J. Seier, Chemosphere 47, 907 (2002).

103. S. Sjostrom, M. Durham, C.J. Bustard, and C. Martin, Fuel 89, $1320(2010)$

104. K. Svoboda, M. Hartman, M. Šyc, M. Pohořelý, P. Kameníková, M. Jeremiáš, and T. Durda, J. Environ. Manag. 166, 499 (2016)

105. R.D. Vidic and J.B. McLaughlin, J. Air Waste Manag. Assoc. 46, 241 (1996).

106. G.O. Storheil, Personal Communication by Electronic Mail to P.A. Eidem on August 24, 2017.

107. A.M. Zykov, L.G. Anichkov, L.K. Korshevets, E.D. Strel'tsova, M. Leonova, S. Durkee, S. Serre, N. Hutson, G. Futsaeter, W. Jozewicz, and J. Munthe, Report, UNEP, USEPA and IVL (2015) 
108. O. Petzoldt, H. Fell, and H. Bräuer, Removal of mercury from gases by modified zeolites in a stationary bed, in Mercury Contaminated Sites (Springer, 1999), p. 393.

109. F. Dyvik, Mercury elimination by the Boliden-Norzink process and recovery of mercury by electrowinning technology, in Rare Metals (Proceedings of the International Symposium on Processing of Rare Metals, Kitakyushi, 1990).

110. M. Gonser and T. Hogan, Arc Welding Health Effects, Fume Formation Mechanisms, and Characterization Methods, ed. W. Sudnik (Rijeka: INTECH, 2011), .

111. K. Yamamoto, T. Mimura, S. Ito, and T. Onoye. Decarburization of molten ferro-manganese in combined blowing converter, in 4th Japan-Nordic Countries Joint Symposium on Science and Technology of Process Metallurgy (The Iron and Steel Institute of Japan (ISIJ), Tokyo, 1986).

112. K. Yamamoto, T. Mimura, S. Ito, and T. Onoye, Tetsu To Hagane-J. Iron Steel Inst. Jpn. 73, 1073 (1987).

113. Y.E. Lee and L. Kolbeinsen, ISIJ Int. 45, 1282 (2005).

114. E.T. Turkdogan, P. Grieveson, and L.S. Darken, J. Phys. Chem. 67, 1647 (1963).

115. B.-D. You, B.-W. Lee, and J.-J. Pak, Met. Mater. 5, 497 (1999).

116. Y. Ma, I. Kero, and G. Tranell, Oxidation of Metals (2017).

117. I. Kero, D. Slizovskiy, B. Wittgens, and G. Tranell, Fume formation from liquid ferromanganese, in Sustainable Industrial Processing Summit (SIPS)_Takano International Symposium on Metals and Alloys (Flogen Stars Outreach, Antalya, 2015).

118. I. Kero and G. Tranell. Active oxidation and fume formation from liquid SiMn, in TMS Annual Meeting (Wiley, Nashville, 2016).

119. Y. Thomassen, D.G. Ellingsen, S. Hetland, and G. Sand, J. Environ. Monit. 3, 555 (2001).

120. D.G. Ellingsen, S.M. Hetland, and Y. Thomassen, J. Environ. Monit. 5, 84 (2003).

121. K. Gjønnes, A. Skogstad, S. Hetland, D. Ellingsen, Y. Thomassen, and S. Weinbruch, Anal. Bioanal. Chem. 399, 1011 (2011).

122. S. Gunst, S. Weinbruch, M. Wentzel, H.M. Ortner, A. Skogstad, S. Hetland, and Y. Thomassen, J. Environ. Monit. 2, 65 (2000).

123. S.J. Gates, I. Kero, L. Hunsbedt, and G.M. Tranell, How water mist alters the fuming rate and particle agglomeration during ferromanganese casting, in INFACON $X V$ (Southern African Institute of Mining and Metallurgy (SAIMM), Cape Town, 2018).

124. S.C. Rencken, Analysis of secondary fume generation and capture during the tapping of high carbon ferromanganese, in Department of Chemical Engineering (University of Pretoria, 2013), p. 57.

125. M.K. Naess, N. Smith, G. Tranell, and J.E. Olsen. Experimental study of rate of silica fume formation from active oxidation of liquid silicon, in INFACON XIII (Almaty, Kazakhstan, 2013).

126. M.K. Naess, G. Tranell, J.E. Olsen, N.E. Kamfjord, and K. Tang, Oxid. Met. 78, 239 (2012).

127. M.K. Naess, D.J. Young, J. Zhang, J.E. Olsen, and G. Tranell, Oxid. Met. 78, 363 (2012).

128. S.J. Gates, G. Kornelius, S.C. Rencken, N.M. Fagan, P. Cowx, and L. Els, Clean Air J. 25, 26 (2015).

129. P. Cowx, R. Nordhagen, L. Els, M. Kadkhodabeigi, and I. Kero. The use of fine water sprays to suppress fume emissions when casting refined ferromanganese, in $I N$ FACON XIV (Kyiv, Ukraine, 2015).

130. P. Cowx, C.J.L. Els, R.H. Dreyer, S.J.F. Gates, R. Nordhagen, and K.A. Iversen, A summary of the industrial use of water sprays to suppress fume emissions during the production of FeMn alloys, in INFACON XV (Southern African Institute of Mining and Metallurgy (SAIMM), Cape Town, 2018).

131. S.J.F. Gates, G. Kornelius, I. Kero, and G.M. Tranell. The influence of water vapour on the fuming rate in a ferromanganese system, in TMS Annual Meeting and Exhibi- tion, Energy Materials (Springer \& The Minerals, Metals \& Materials Society, San Diego, 2017).

132. Y. Ma, E. Khoonsari-Moosavi, I. Kero, and G. Tranell. The effect of water vapour on the fume formation in a SiMn system, in INFACON XV (Southern African Institute of Mining and Metallurgy (SAIMM), Cape Town, 2018).

133. S.S. Amaral, J.A. de Carvalho, M.A.M. Costa, and C. Pinheiro, Atmosphere 6, 1327 (2015).

134. S. Grådahl, A. Ferber, T. Aarhaug, and A. Brunsvik, Report No. F21050 - Confidential, SINTEF Materials and Chemistry, P. Technology, Trondheim, Norway (2011).

135. S. Grådahl and H.F. Midtdal, Report No. Draft only, SINTEF Materials and Chemistry, Trondheim, Norway (2013).

136. H.F. Midtdal and B. Panjwani, Report No. F23802-Restricted, SINTEF Materials and Chemistry, Trondheim, Norway (2012).

137. I. Kero, S. Grådahl, H. Fardal, and B. Wittgens, Fugitive dust measurements in the metallurgical industry, in Sustainable Industrial Processing Summit (SIPS)-Takano International Symposium on Metals and Alloys (Flogen Stars Outreach, Antalya, 2015).

138. Kero, I., Report No. F25561 - Restricted, SINTEF Materials and Chemistry, Trondheim, Norway, 2013.

139. I. Kero, M. Naess, and G. Tranell, Fume characterization in the ferroalloy industry, in INFACON XIII (Almaty, Kazakhstan, 2013).

140. I. Kero, M. Naess, and G. Tranell, J. Occup. Environ. Hygiene 12,37 (2015).

141. B. Berlinger, M. Bugge, B. Ulvestad, H. Kjuus, K. Kandler, and D. Ellingsen, Environ. Sci. Process. Impacts 17, 2066 (2015).

142. Report No., World Health Organization Regional Office for Europe (2000)

143. V. Riffault, J. Arndt, H. Marris, S. Mbengue, A. Setyan, L.Y. Alleman, K. Deboudt, P. Flament, P. Augustin, and H. Delbarre, Crit. Rev. Environ. Sci. Technol. 45, 2305 (2015).

144. T. Moreno, M. Pandolfi, X. Querol, J. Lavín, A. Alastuey, M. Viana, and W. Gibbons, Environ. Sci. Pollut. Res. 18, 173 (2011).

145. Report No., Miljø- og Energiministeriet (2001).

146. Report No. Vejledning nr. 20, Miljø- og Fødevareministeriet (2016).

147. A. Hernández-Pellón, I. Fernández-Olmo, F. Ledoux, L. Courcot, and D. Courcot, Chemosphere 175, 411 (2017).

148. S. Mbengue, L.Y. Alleman, and P. Flament, Atmos. Res. 135,35 (2014).

149. I. Fernández-Olmo, C. Andecochea, S. Ruiz, J.A. Fernández-Ferreras, and A. Irabien, Atmos. Res. 171, 92 (2016).

150. L.Y. Alleman, L. Lamaison, E. Perdrix, A. Robache, and J.C. Galloo, Atmos. Res. 96, 612 (2010).

151. E.N. Haynes, P. Ryan, A. Chen, D. Brown, S. Roda, P. Kuhnell, D. Wittberg, M. Terrell, and T. Reponen, Sci. Total Environ. 427-428, 19 (2012).

152. R.K. Xie, H.M. Seip, J.R. Leinum, T. Winje, and J.S. Xiao, Sci. Total Environ. 343, 261 (2005).

153. E. Lucas, P. Bertrand, S. Guazzetti, F. Donna, M. Peli, T. Jursa, R. Lucchini, and D. Smith, Environ. Res. 138, 279 (2015).

154. B.T. Pavilonis, P.J. Lioy, S. Guazzetti, B.C. Bostick, F Donna, M. Peli, N.J. Zimmerman, P. Bertrand, E. Lucas, and D.R. Smith, J. Exposure Sci. Environ. Epidemiol. 25, 443 (2015).

155. E.N. Haynes, P. Heckel, P. Ryan, S. Roda, Y.-K. Leung, K. Sebastian, and P. Succop, NeuroToxicology 31, 468 (2010).

156. L. Borgese, A. Zacco, S. Pal, E. Bontempi, R. Lucchini, N. Zimmerman, and L.E. Depero, Talanta 84, 192 (2011).

157. E. Steinnes, M. Frontasyeva, S. Gundorina, and Y.S. Pankratova, Chem. Anal. (Warsaw) 53, 877 (2008).

158. S. Nickel, W. Schröder, W. Wosniok, H. Harmens, M.V. Frontasyeva, R. Alber, J. Aleksiayenak, L. Barandovski, O Blum, and H. Danielsson, Atmos. Environ. 156, 146 (2017)

159. C. Borrego, A. Costa, J. Ginja, M. Amorim, M. Coutinho, K. Karatzas, T. Sioumis, N. Katsifarakis, K. Konstantinidis, and S. De Vito, Atmos. Environ. 147, 246 (2016). 
160. C. Acciai, Z. Zhang, F. Wang, Z. Zhong, and G. Lonati, Aerosol Air. Qual. Res. 17, 2224 (2017)

161. N. Castell, F.R. Dauge, P. Schneider, M. Vogt, U. Lerner, B. Fishbain, D. Broday, and A. Bartonova, Environ. Int. 99, 293 (2017).

162. P. Schneider, N. Castell, M. Vogt, F.R. Dauge, W.A. Lahoz, and A. Bartonova, Environ. Int. 106, 234 (2017).
163. V. Bankovitch, G. Carrier, C. Gagnon, L. Normandin, G. Kennedy, and J. Zayed, Sci. Total Environ. 308, 185 (2003).

164. H. Marris, K. Deboudt, P. Augustin, P. Flament, F. Blond, E. Fiani, M. Fourmentin, and H. Delbarre, Sci. Total Environ. 427, 126 (2012). 